Article

\title{
Factors Affecting Green Entrepreneurship Intentions in Business University Students in COVID-19 Pandemic Times: Case of Ecuador
}

\author{
Aldo Alvarez-Risco ${ }^{1, *(\mathbb{D})}$, Sabina Mlodzianowska ${ }^{2}(\mathbb{D})$, Verónica García-Ibarra ${ }^{3}$, Marc A. Rosen ${ }^{4}(\mathbb{D}$ \\ and Shyla Del-Aguila-Arcentales ${ }^{5}$ (D)
}

Citation: Alvarez-Risco, A.; Mlodzianowska, S.; García-Ibarra, V.; Rosen, M.A.; Del-Aguila-Arcentales,

S. Factors Affecting Green

Entrepreneurship Intentions in

Business University Students in COVID-19 Pandemic Times: Case of Ecuador. Sustainability 2021, 13, 6447. https://doi.org/10.3390/su13116447

Academic Editors: José

Carlos Sánchez-García and

Fernando Almeida

Received: 11 April 2021

Accepted: 28 May 2021

Published: 6 June 2021

Publisher's Note: MDPI stays neutral with regard to jurisdictional claims in published maps and institutional affiliations.

Copyright: (c) 2021 by the authors. Licensee MDPI, Basel, Switzerland. This article is an open access article distributed under the terms and conditions of the Creative Commons Attribution (CC BY) license (https:// creativecommons.org/licenses/by/ $4.0 /)$.
1 Carrera de Negocios Internacionales Facultad de Ciencias Empresariales y Económicas, Universidad de Lima, Lima 15023, Peru

2 Escuela de Posgrado, Universidad de Lima, Lima 15023, Peru; smlodzia@ulima.edu.pe

3 Carrera de Administración de Empresas, Universidad Politécnica Estatal del Carchi, Tulcan 040102, Ecuador; veronica.garcia@upec.edu.ec

4 Faculty of Engineering and Applied Science, University of Ontario Institute of Technology, 2000 Simcoe Street North, Oshawa, ON L1G 0C5, Canada; marc.rosen@uoit.ca

5 Escuela Nacional de Marina Mercante "Almirante Miguel Grau", Callao 07021, Peru; sdelaguila@enamm.edu.pe

* Correspondence: aralvare@ulima.edu.pe

\begin{abstract}
This research assesses the influence of education development support, conceptual development support, and country support through entrepreneurial self-efficacy over green entrepreneurial intentions. A total of 532 business students in Ecuador participated in an online survey. Eight questions were focused on demographic information, and twenty-seven questions evaluated the green entrepreneurship intentions of students. An SEM-PLS technical analysis was used. The results showed that educational support for developing entrepreneurship (0.296), conceptual support for developing entrepreneurship (0.123), and country support for entrepreneurship (0.188) had a positive influence on entrepreneurial self-efficacy, and that entrepreneurial self-efficacy had a positive influence (0.855) on gren entrepreneurial intentions. The model explained $73.1 \%$ of the green entrepreneurial intentions. Outcomes of the bootstrapping test were used to evaluate if the path coefficients are significant. This study showed the impacts of education development support, conceptual development support, and country support on the entrepreneur's ability to carry out green entrepreneurship were positive. This information can help universities develop strategic plans to achieve ecological ventures and ensure students have the necessary skills to do so on campus. The research findings also may be helpful for the governments in establishing new norms to promote entrepreneurship. The novelty is based on using the partial least square structural equation modeling (PLS-SEM) technique.
\end{abstract}

Keywords: green entrepreneurship intention; green entrepreneurship; business students; Ecuador; university; COVID-19; sustainability; sustainable development goals

\section{Introduction}

Since December 2019, the world has been changed dramatically by the Coronavirus (COVID-19), an infectious disease of pandemic dimensions, with approximately 158,000,000 cases and 3.3 million deaths reported worldwide as of 10 May 2021 [1]. The pandemic has generated adverse effects both at the individual and the collective level. The health system offers various services [2-11], but the COVID-19 pandemic negatively impacted health professionals [12-16] and individuals [17-20], both in their expectations [21] and in their usual activities such as education [22]. A similar impact has happened in previous epidemics [23]. 
One of the sectors more impacted by COVID-19 was tourism, which is usually highly in demand [24-27]. The negative impact of COVID-19 at the collective level was reported in companies [28] and finally in the global economy [29], and it has spawned alternative forms of labor survival such as entrepreneurship. However, it has been proposed to promote entrepreneurship activities to help address and combat the COVID-19 crisis [30]. At the same time, efforts are needed to address the Sustainable Development Goals (SDGs) to address the damage caused by COVID-19 [31]. For that, it is expected that environmental ventures may be among the most common, so it is essential to know the factors involved. Environmental and ecological protection efforts are constantly increasing [32]. In 1972, universities reported the need to promote the learning and development of activities focused on entrepreneurship [33]. Ten years later, university experiences of entrepreneurship in Canada were reported [34], and it was possible to identify weaknesses in university education regarding the knowledge and skills necessary for entrepreneurship. At the same time, the role of universities in promoting business development from theoretical and practical academic training was identified [35], which provides added value to universities [36]. Gradually, university education in many jurisdictions has been orienting more towards entrepreneurship $[37,38]$.

Since many universities need to develop specific programs to promote entrepreneurship, it is necessary to know and understand the factors that explain students' intentions regarding green entrepreneurship and have detailed knowledge of if and how the university promotes entrepreneurship on campus through campus and virtual events. It is also essential to determine whether the university generates connections between start-ups and students to create awareness and stimulate learning of practical knowledge so students have the tools to create companies. Countries usually generate support for entrepreneurship, and it is essential to know the perception of the support that students have. The various factors are evaluated to understand the aspects that influence their intentions regarding environmental or ecological work from student perspectives.

This study aims to measure some critical variables. First, we evaluate the influence of conceptual development support, which is understood as the support given by the University in terms of motivation and the provision of new ideas to students to start a new venture. Another variable that is examined is country support, which measures the support provided by the country in terms of laws and state programs to encourage entrepreneurship. Education development support is also measured, linked to the regular courses that the university offers on entrepreneurship and the impulse to develop projects, pre-professional practices, and connections with entrepreneurs. Another variable measured, which constitutes the mediating variable in this study, is entrepreneurial self-efficacy, which is the conviction that the student has of being able to carry out entrepreneurship and launch an enterprise. Finally, the student's intention to carry out green entrepreneurship is evaluated through a variable called green entrepreneurial intention.

The rest of the paper is structured as follows: Section 2 presents relevant background, including different concepts about green entrepreneurship and its factors. The methodology, with a description of the instrument, sample, and data process, is provided in Section 3. Section 4 gives the outcomes according to the questionnaire applied. Section 5 presents a discussion of the findings. Conclusions with theoretical, practical, and societal implications and recommendations, including potential future research, are provided in Section 6.

\section{Literature Review}

The experiences of entrepreurship education in universities have been studied in various countries. Numerous initial reports on entrepreneurship in universities analyzed European countries. For instance, Frazier on Poland [39], Johannisson on Sweden [40], van der Sijde and van Aslté on the Netherlands [41], Tamkivi on Estonia [42], Watkins and Stone on the UK [43], Kloften and Jones-Evans on Ireland [44], Virtanen and Laukkanen on Finland [45], Campanella, Della and Del Giudice on Italy [46], Klandt and Volkmann on Germany [47], Edwards and Muir on Wales [48], Karanassios et al. on Greece [49], 
Toledano y Coduras et al. on Spain [50] and Ferreira, Raposo and do Paço on Portugal [51]. Further studies presented situations in Asia, for example Huu-Phuong [52] in Singapore, Menning in India [53], Suzuki, Kim and Bae in Japan [54], Mok in Hong Kong [55], Yu, Sei, and Mahmood in Malaysia [56], Millman, Matlay and Liu in China [57].

There are also studies available from Australia by Mitra [58], and from Africa, including Jesselyn and Mitchell in South Africa [59], Owusu-Mintah in Ghana [60], and Olokundun et al. [61]. In the case of the Americas, studies were reported from Canada by Chrisman, Hynes, and Fraser [62], the United States by Dill [63], Chile by Bernasconi [64] and Argentina by Postigo, and Tamborini [65]. Further, a critical study in entrepreneurship in some Latin American countries was carried out by Chafloque-Cespedes et al. [66]. Regarding green entrepreneurship, this subject was studied by Silajdžić, Kurtagić, and Vučijak in Bosnia and Herzegovina [67], Linskey in Japan [68], and Bonnet et al. in the Netherlands [69]. More recently, some investigations have identified different variables that have an influence of green entrepreneurship intentions [70].

\subsection{Theory}

\subsubsection{Theory of Reasoned Action}

The current study considers the theory of planned behavior (TPB) as a theoretical foundation to calculate the effect of contextual elements and self-efficacy on carrying out green entrepreneurship. Fishbein and Ajzen [71] proposed that TPB explains the factors that describe people's intentions behind the factors described by self-efficacy. Likewise, it includes intentions as a strong predictor of behavior. A country's laws or policies regarding green entrepreneurship intentions need to foster the self-efficacy to develop entrepreneurial activities.

\subsubsection{Theory of Social Cognitive}

Additionally, for this study, the theory of social cognitive developed by Bandura [72] is relevant, which emphasizes the belief that behaviors are within the individual's control and can augment self-efficacy. These aspects are reflected in the development of motivations to carry out entrepreneurial activities, educational supports for green entrepreneurship, and laws and policies that facilitate these undertakings.

Entrepreneurship orientation is a matter of constant evaluation in theoretical and practical research. Since Miller [73] began studying this variable, many investigations have been reported to understand the variables linked to this orientation and that ultimately impact the intention to carry out undertakings at different levels and of different types such as social or ecological entrepreneurship. Lumpkin and Dess [74] established in a general way that it has been possible to conceptualize the entrepreneurial orientation as the tendency towards decision-making that favors commercial activities' performance. The model of the present research also seeks to evaluate how the different types of support existing in the educational ecosystem as well as at the governmental level influence the entrepreneurial self-efficacy of students to increase the intention to develop green enterprises, which are less common.

\section{Approach}

\subsection{Development of Hypothesis}

\subsubsection{Green Entrepreneurial Intention}

The intention is the individual's state that creates decisions, attention, and interest to carry out a specific action [75-77]. Various factors affect the intention to act and directly affect the behavior. These can show how a person plans to carry out the linked behavior as indicated by the TPB [78]. The intention to perform a behavior precedes the behavior as such. There is evidence that entrepreneurship tends to positively influence entrepreneurship development $[76,79,80]$. Entrepreneurship is a concept that applies to both individuals and companies [73]. Green entrepreneurship involves additional concepts. Thus, we have the definition proposed by Farinelli [81], who states that green entrepreneurship is 
implementing innovations related to sustainability, with a focus on promoting the green economy among clients. Despite this intention of green entrepreneurship, entrepreneurs experience a problem establishing when an undertaking is green or not, so these undertakings are defined from the research results to facilitate their understanding. Thus, we can argue that green entrepreneurship involves addressing environmental issues and has a positive impact, such as the use of eco-friendly inputs, clean manufacturing processes, waste management, and recycling, among others. In other words, we not only talk about ecological entrepreneurship as a purpose of environmental care, but also approval of suppliers, purchase of materials, and clean processes. However, the definitions are likely to continue to be the subject of research and debate. In this study, we consider the intention of developing green entrepreneurship by university students.

\subsubsection{Country Support for Entrepreneurship}

This variable is understood as initiatives developed in a country to collaborate in ventures [82]. The variable allows descriptions of what the student thinks about the country's promotion and support activities for environmental and ecological ventures. Another factor measures if the student feels that the country offers options for developing ventures, which can be assessed as perceptions of easy to obtain bank loans for carrying out ventures. It is necessary to measure if country support influences self-efficacy for the development of ecological entrepreneurship. Therefore, the following hypothesis is formed:

Hypothesis 1 (H1). Country support for entrepreneurship has a positive influence on entrepreneurial self-efficacy.

\subsubsection{Educational Support for Developing Entrepreneurship}

This construct is understood as universities' training activities to develop ventures [83]. The educational support focuses on offering compulsory subjects that describe how to develop ventures, including real projects to learn about the development of ventures; additionally, it focuses on offering pre-professional practice in firms focused on entrepreneurship orientation. This construct is also measured regarding whether conferences and academic workshops are held to develop competencies and obtain better knowledge about ventures, including linking students with successful entrepreneurs. It is essential to measure if education development support influences self-efficacy for the development of ecological entrepreneurship. For that, the following hypothesis is formed:

Hypothesis 2 (H2). Educational support for developing entrepreneurship has a positive influence on entrepreneurial self-efficacy.

\subsubsection{Conceptual Support for developing Entrepreneurship}

This construct is understood as the university's efforts to provide technical knowledge about entrepreneurship and, in this way, contribute to awareness about entrepreneurship in students who can develop successful ventures, motivating students for the creation of new ventures [84]. Also included in this construct are generating new business ideas, both in the environmental and social fields, and considering a business approach. It is helpful to measure whether the conceptual development support influences self-efficacy for the development of ecological entrepreneurship. For that, the following hypothesis is formed:

Hypothesis 3 (H3). Conceptual support for developing entrepreneurship has a positive influence on entrepreneurial self-efficacy.

\subsubsection{Entrepreneurial Self-Efficacy}

This variable is the belief that a person has about their ability to do any activity successfully and incorporate concrete behaviors into their daily agenda [85,86]. Entrepreneurial self-efficacy refers to the person's confidence in developing entrepreneurial activities and 
ultimately generating ventures $[87,88]$. Research evidence indicates the positive influence of entrepreneurial self-efficacy over entrepreneurial intention [89-91], which can be understood as people having a high level of self-efficacy, and is more likely to start ventures. The same applies to green businesses, which are of great importance in these times of COVID-19 [92]. For that, the following hypothesis is formed:

Hypothesis 4 (H4). Entrepreneurial self-efficacy has a positive influence on green entrepreneurial intention.

\subsection{Research Model}

Figure 1 shows the research model detailing the relationship between the study variables. The model includes education development support, conceptual development support, and country support through entrepreneurial self-efficacy and green entrepreneurial intention. The circles represent each variable of the study, and the rectangular boxes indicate items for each variable.

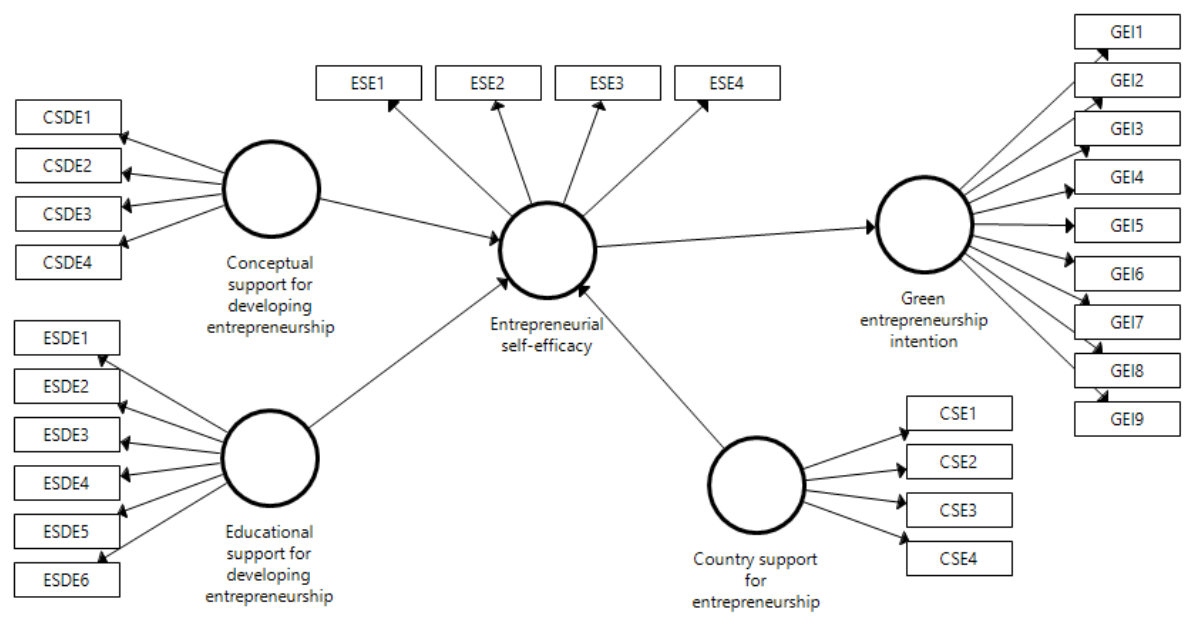

Figure 1. Research model.

\section{Methodology}

The methodology used in the current study includes an observational study with both descriptive and inferential design. The aim is to identify and describe the factors that can explain the intention of green entrepreneurship.

\subsection{Sample}

The study involved business university students from Ecuador. As inclusion criteria, business students from universities in Ecuador and 18 years and older were considered. As exclusion criteria, students in the first year were not considered. The sample consists of 532 participants, 199 men $(37.4 \%)$ and 323 women (62.6\%), ranging between 18 and 29 years. The average age was 22.6, with a standard deviation of 2.9 years.

\subsection{Data Collection and Instrument}

The data collection used a questionnaire in Google Forms, which was run online 10 to 15 February 2021. The data collection using the online questionnaire was distributed to business university students by email and personal chats. For ethical purposes, the questionnaire was applied to students who agreed to participate after reading the statement, "your participation is voluntary; therefore, the information obtained will be confidential and will only be used for research purposes".

The questionnaire used has two sections. The first collects sociodemographic data from the business university students. The second section includes original questions and questions based on other instruments in the following areas: education development 
support [93], conceptual development support [93], country support (current authors), entrepreneurial self-efficacy [94], and green entrepreneurial intention [93,95,96]. The original items were translated and adapted linguistically. The variables are measured using a 5-point Likert-type scale (where $1=$ completely disagree, to $5=$ completely agree). The scale of education development support consists of six items, conceptual development support four items, country support four items, entrepreneurial self-efficacy four items, and entrepreneurial intention eight items. The first version of the online questionnaire was checked by sustainability and entrepreneurship experts. The final version of the questionnaire was uploaded in Google Forms. The students completed the online form anonymously. At the beginning of the questionnaire, students were informed of the aim of the research, and informed consent was obtained.

\subsection{Data Analysis}

To evaluate the data collected, SPSS version 26 and SmartPLS version 3.3.2 were employed. Sometimes doubts arise about the need to compare between using PLS-SEM and covariance-based structural equation modeling (CB-SEM), but it is important to understand that they are complementary methods [97]. PLS-SEM does not seek to mimic CB-SEM $[98,99]$. The following is recommended [100]: a. If the objective is predicting key target constructs or identifying key 'driver' constructs, select PLS-SEM. b. If the goal is theory evaluation, confirmation of a theory, or comparison of two or more theories, select CB-SEM. c. If the study is exploratory or an extension of an existing structural theory, select PLS-SEM.

Additionally, Rigdon et al. [100] and Sarstedt et al. [101] identified differences regarding when to use PLS-SEM and CB-SEM.

PLS-SEM must be used when:

a. The objective is predicting key target constructs or identifying key "driver" constructs.

b. The structural model is complex (some constructs and some indicators).

c. The plan is to use construct scores in subsequent analyses.

CB-SEM must be used when:

a. The objective is theory evaluation, theory confirmation, or the comparison of different theories.

b. The structural model has circular relationships.

c. The study needs a global goodness-of-fit criterion.

Likewise, SEM PLS is used for samples that do not have a normal distribution and require a non-parametric analysis, as does the current study. Further, SEM PLS delivers the $\mathrm{R} 2$ values and, at the same time, indicates the significance of relationships between constructs to demonstrate how well the model is performing. In the case of CB-SEM, only path modeling is provided. Finally, SEM PLS can handle many independent variables simultaneously [102]. All these reasons explain and support the choice to use PLS-SEM for the current study. The internal consistency of each subscale was analyzed using Cronbach's alpha reliability coefficient, construct and discriminant validity, and internal consistency through composite reliability [97]. The reliability of each indicator is evaluated by measuring the indicator's loads and their dimensions. The average extracted variance is utilized to analyze the fit of the model. In addition, the Fornell-Larcker criterion [98,99] is used to evaluate the discriminant validity.

\section{Results}

\subsection{Reliability}

The reliability of scales obtained by analysis of internal consistency is listed in Table 1. The variables' scales showed reliability coefficients (Cronbach's Alpha) higher than the expected minimum of 0.5 in the exploratory analysis (see Table 1). 
Table 1. Reliability of scales by analysis of internal consistency.

\begin{tabular}{cccc}
\hline Scales & $\mathbf{N}^{\circ}$ of items & $\begin{array}{c}\text { Cronbach's } \\
\text { Alpha }\end{array}$ & Range of Items Scores \\
\hline $\begin{array}{c}\text { Conceptual support for } \\
\text { developing entrepreneurship } \\
\text { Educational support for } \\
\text { developing entrepreneurship }\end{array}$ & 6 & 0.951 & $0.923-0.943$ \\
$\begin{array}{c}\text { Country support for } \\
\text { entrepreneurship }\end{array}$ & 4 & 0.926 & $0.776-0.884$ \\
$\begin{array}{c}\text { Entrepreneurial self-efficacy } \\
\text { Green entrepreneurial } \\
\text { intention }\end{array}$ & 4 & 0.858 & $0.804-0.880$ \\
\hline
\end{tabular}

Sample: 532 business students.

\subsection{Validation with SEM-PLS}

The instrument's validation by SEM-PLS includes a reliability analysis of each item, the internal consistency of dimensions using composite reliability, analysis of the average variance extracted, and discriminant validity. An acceptable value of composite reliability is more significant than 0.707 . The coefficients of reliability composed of each instrument's sub-scales were between 0.555 and 0.943 (see Table 2). Values obtained in the sub-scales are observed to confirm the reliability of the instrument.

Table 2. Construct validity of the items of the scales using Structural Equations of Variance using Partial Least Squares.

\begin{tabular}{|c|c|c|c|}
\hline Scale-Items & $\begin{array}{c}\text { Factorial } \\
\text { Weight }\end{array}$ & $\begin{array}{l}\text { Composite } \\
\text { Reliability }\end{array}$ & $\begin{array}{l}\text { Extracted } \\
\text { Variance }\end{array}$ \\
\hline Educational support for developing entrepreneurship & & \multirow{7}{*}{0.942} & \multirow{7}{*}{0.731} \\
\hline My university offers elective courses on entrepreneurship & 0.837 & & \\
\hline My university offers project work focused on entrepreneurship & 0.884 & & \\
\hline My university offers practices focused on entrepreneurship & 0.895 & & \\
\hline My university offers a bachelor's or master's degree study in entrepreneurship & 0.776 & & \\
\hline My university organize conferences/workshops on entrepreneurship & 0.869 & & \\
\hline My university connects students with entrepreneurs & 0.865 & & \\
\hline Conceptual support for developing entrepreneurship & & \multirow{5}{*}{0.965} & \multirow{5}{*}{0.873} \\
\hline My university creates awareness of entrepreneurship as a possible career choice & 0.923 & & \\
\hline My university motivates students to start a new venture & 0.943 & & \\
\hline My university provides students with ideas to start a new venture & 0.935 & & \\
\hline My university provides students with the knowledge needed to start a new venture & 0.935 & & \\
\hline Country support for entrepreneurship & & \multirow{5}{*}{0.904} & \multirow{5}{*}{0.701} \\
\hline In my country, green entrepreneurs are encouraged by an institutional structure & 0.845 & & \\
\hline My country's economy offers many opportunities for entrepreneurs & 0.804 & & \\
\hline Obtaining bank loans is quite difficult for entrepreneurs in my country & 0.819 & & \\
\hline The state laws of my country are adverse to the management of a company & 0.880 & & \\
\hline Entrepreneurial self-efficacy & & \multirow{5}{*}{0.934} & \multirow{5}{*}{0.780} \\
\hline Creating and maintaining an ecological venture is a task that I can do & 0.861 & & \\
\hline I have the necessary knowledge to develop an ecological venture & 0.879 & & \\
\hline I have enough skills to develop an ecological venture & 0.890 & & \\
\hline I believe that in the future, I will be able to develop a successful green venture & 0.902 & & \\
\hline
\end{tabular}


Table 2. Cont.

\begin{tabular}{|c|c|c|c|}
\hline Scale-Items & $\begin{array}{c}\text { Factorial } \\
\text { Weight }\end{array}$ & $\begin{array}{l}\text { Composite } \\
\text { Reliability }\end{array}$ & $\begin{array}{l}\text { Extracted } \\
\text { Variance }\end{array}$ \\
\hline Green entrepreneurial intention & & & \\
\hline I plan to develop a venture that addresses the ecological problems of my community & 0.860 & & \\
\hline I recommend to my colleagues to develop enterprises that solve ecological problems & 0.782 & & \\
\hline My future initiatives will prioritize ecological benefits over financial ones & 0.862 & & \\
\hline If I had the opportunity and the resources, I would definitely go green. & 0.815 & 0.953 & 0.695 \\
\hline I have seriously thought about becoming a green entrepreneur & 0.873 & & \\
\hline I will do my best to start and run my own green venture & 0.880 & & \\
\hline I have the firm intention of starting an ecological venture one day & 0.906 & & \\
\hline I propose to undertake and act in the management of my own ecological venture & 0.911 & & \\
\hline It is safer to work in a company than to risk a green business & 0.555 & & \\
\hline
\end{tabular}

Sample: 532 business students.

\subsection{Discriminant Validity Using SEM-PLS}

Discriminant validity was calculated using the Fornell-Larcker criterion [98], as shown in Table 3. To do this, in the first column, the square root of the extracted variance that appears in the upper part in parentheses must be greater than the correlations that appear in the same column in the following lines of the same column. This criterion is applied for each column. Table 3 shows the fulfillment of this criterion in all the subscales, demonstrating the discriminant validity of the tested instrument.

Table 3. Discriminant validity of sub-scales using the Fornell-Larcker criterion.

\begin{tabular}{cccccc}
\hline Scales & CSDE & CSE & ESDE & ESE & GEI \\
\hline CSDE & $\mathbf{( 0 . 9 3 4 )}$ & & & & \\
CSE & 0.466 & $\mathbf{( 0 . 8 3 8 )}$ & & & \\
ESDE & 0.847 & 0.468 & $\mathbf{( 0 . 8 5 5 )}$ & & \\
ESE & 0.461 & 0.384 & 0.488 & $\mathbf{( 0 . 8 8 3 )}$ & \\
GEI & 0.462 & 0.381 & 0.472 & 0.855 & 0.833 \\
\hline
\end{tabular}

Sample: 532 business students.

Conceptual support for developing entrepreneurship: CSDE; Country support for entrepreneurship: CSE; Educational support for developing entrepreneurship: ESDE; Entrepreneurial self-efficacy: ESE; Green entrepreneurial intention: GEI.

\subsection{Bootstrapping}

The Bootstrapping Technique is a non-parametric procedure used to evaluate if the path coefficients (beta) are significant [100]. Bootstrapping is a statistical technique for estimating quantities over a population by averaging estimates from multiple small data samples. Samples are constructed by extracting observations from a large data sample one at a time and returning them to the data sample after they have been chosen, which allows a given observation to be included in a given small sample more than once. This sampling approach is called replacement sampling. In order to efficiently calculate if the tested model is significant, the calculation is carried out, indicating in the software that it is to be carried out 5000 times. It is seen in Table 4 that three values are significant ( $p$ values $<0.01$ ). 
Table 4. Significance of trajectory coefficients (beta).

\begin{tabular}{cccccc}
\hline Scales & $\begin{array}{c}\text { Original } \\
\text { Sample }\end{array}$ & $\begin{array}{c}\text { Mean } \\
\text { Sample }\end{array}$ & $\begin{array}{c}\text { Standard } \\
\text { Deviation }\end{array}$ & t-Statistic & $p$ \\
\hline $\mathrm{CSDE} \rightarrow$ ESE & 0.123 & 0.121 & 0.075 & 1.636 & 0.102 \\
$\mathrm{CSDE} \rightarrow$ ESE & 0.188 & 0.189 & 0.047 & 3.966 & 0.000 \\
$\mathrm{ESDE} \rightarrow$ ESE & 0.296 & 0.297 & 0.074 & 4.012 & 0.000 \\
$\mathrm{ESE} \rightarrow$ GEI & 0.855 & 0.855 & 0.015 & 56.807 & 0.000 \\
\hline
\end{tabular}

Bootstrapping technique (5000 times) using Smart PLS. $p$-value $<0.01$. Sample: 532 business students.

Conceptual support for developing entrepreneurship: CSDE; Country support for entrepreneurship: CSE; Educational support for developing entrepreneurship: ESDE; Entrepreneurial self-efficacy: ESE; Green entrepreneurial intention: GEI.

Figure 2 shows the research model tested. The results confirm that education development support, conceptual development support, and country support through self-efficacy influence green entrepreneurship intention in business students.

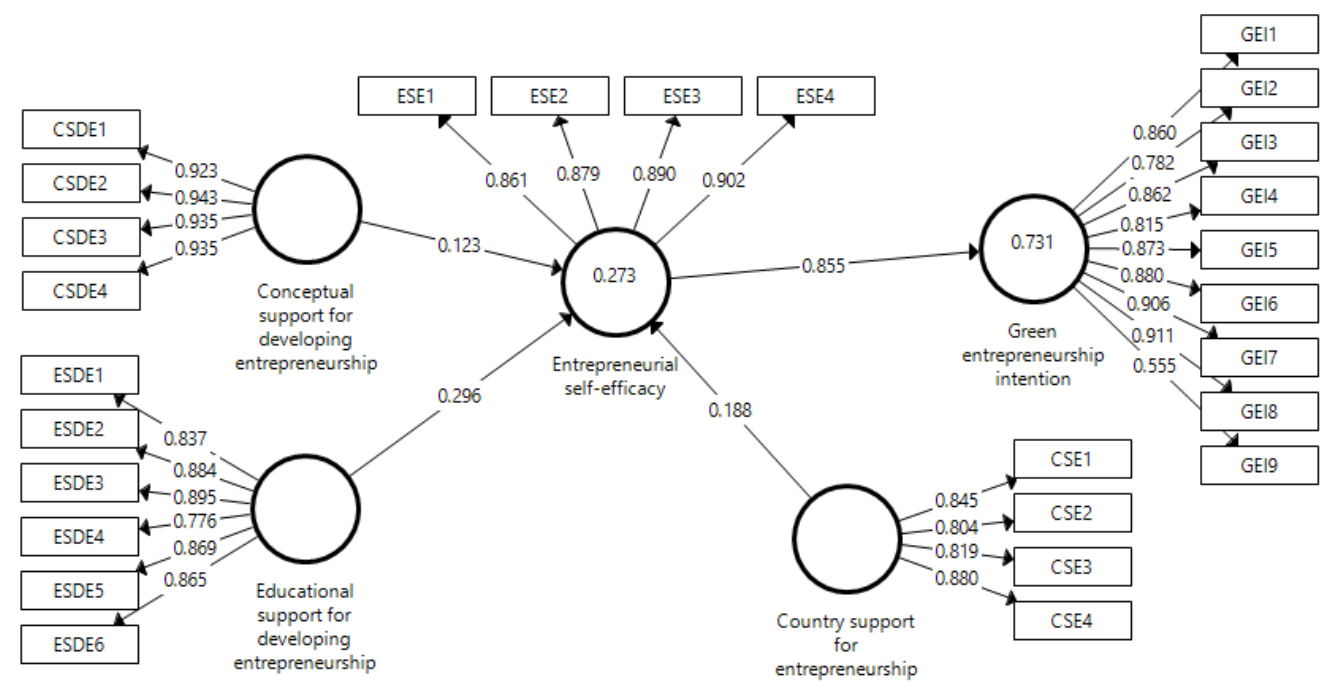

Figure 2. Research model tested.

\subsection{Test of Hypothesis}

Hypothesis 1 (H1). Country support for entrepreneurship has a positive influence on Entrepreneurial self-efficacy.

Country support has a positive influence of 0.188 over Entrepreneurial self-efficacy. The hypothesis was confirmed. Country support and educational support for developing entrepreneurship and Conceptual support for developing entrepreneurship explain 27.3\% of Entrepreneurial self-efficacy.

Hypothesis 2 (H2). Educational support for developing entrepreneurship has a positive influence on Entrepreneurial self-efficacy.

Educational support for developing entrepreneurship has a positive influence of 0.296 over Entrepreneurial self-efficacy. The hypothesis was confirmed.

Hypothesis 3 (H3). Conceptual support for developing entrepreneurship has a positive influence on Entrepreneurial self-efficacy. 
Conceptual development support has a positive influence of 0.123 over Entrepreneurial self-efficacy. The hypothesis was confirmed.

Hypothesis 4 (H4). Entrepreneurial self-efficacy influences Green entrepreneurship intention.

Entrepreneurial self-efficacy has a positive influence of 0.855 over Green entrepreneurship intention. The hypothesis was confirmed.

The complete model explains the $73.1 \%$ of Green entrepreneurship intention.

\section{Discussion}

The current study's objective is to evaluate the influence of educational support for developing entrepreneurship, conceptual support for developing entrepreneurship, and country support for entrepreneurship through entrepreneurial self-efficacy over green entrepreneurial intention in business students in Ecuador. We ensured that the questionnaire could be trusted, calculating the discriminant validity and reliability (internal consistencyCronbach's alpha coefficient and composite reliability). The outcomes obtained showed that the instrument was valid, reliable, and statistically relevant in applying the sample and can show if the model explains the factors that describe green entrepreneurship intention.

The influence of education development support on entrepreneurial self-efficacy verified in the present study is similar to that reported by Shi et al. [101] for 374 Chinese university students. Likewise, this relationship could be verified in the study of Mozahem and Adlouni [102] for 560 university students from Lebanon, and the results coincide with the findings for 376 university students in Indonesia [103]. It is relevant to know if universities are offering careers focused on entrepreneurship or offering postgraduate programs in entrepreneurship such, as is done at the University of Melbourne [104] and Amsterdam Business School [105]. It is also relevant to confirm that universities benefit from organizing conferences on entrepreneurship since the preliminary results of entrepreneurship efforts can be disseminated and generate contact with successful entrepreneurs, who can relate their experiences and motivate students to undertake entrepreneurship.

The influence of conceptual development support on entrepreneurial self-efficacy verified in the present study is similar to that reported by Burnette et al., who conducted a study in the USA on 238 undergraduate students [106]; likewise, the result identified here coincides with that found in a study of 109 undergraduate university students from South Africa [107], as well as with the results reported by Cadenas [108] in the USA, Shi et al. [101] in China, and Elnadi and Gheith [109] in Saudi Arabia. It is essential to know if a university has focused on creating awareness about entrepreneurship by influencing so that students at the end of their studies can choose entrepreneurship as a professional career. Similarly, the motivation that students may have to start a new business is valued. Among the most significant aspects is knowledge of whether the university provides in an organized and systematic way ideas to generate new businesses based on entrepreneurship. In this sense, it is important that future researchers specifically ask whether universities have think-tanks, such as those at the University of Oxford [110] and Harvard University [111].

The influence of country support on entrepreneurial self-efficacy verified in the present study is similar to that reported by Memon, et al. [112], who evaluated 564 university students from Pakistan. Similar results were found in the study by Nowiński, et al. [113], who evaluated 360 university students in the USA and 1054 university students in Poland. When entrepreneurship is evaluated, the question has usually been evaluated of whether institutional support is received. However, very rarely is the support given by governments for ecological entrepreneurship evaluated. Therefore, it is helpful to evaluate this support from the country, which also has to modify specific laws and move the state and the banks to promote investment in green enterprises, with guaranteed loans at reasonable rates so as to encourage new green entrepreneurs. Country support for entrepreneurship together with educational support for developing entrepreneurship and conceptual support for developing entrepreneurship explains $17 \%$ of self-efficacy. 
The relation between the variables is very relevant since it allows us to understand how the influences between the variables discussed in the current study can make students feel that they can carry out green ventures based on the knowledge obtained. The skills developed due to supports provided through courses, practices, and the country's regulatory framework. These aspects build confidence in students to develop green ventures that also contribute to the SDGs.

The influence of self-efficacy on green entrepreneurship intention demonstrated in the present study is similar to that reported by Soomro et al. [114] in a study of 284 university students from Pakistan. Little research has been carried out specifically on ecological entrepreneurship intention, so this study provides a reference for Latin America. There is significant growth in entrepreneurship, providing an excellent opportunity to implement green entrepreneurship, with a corresponding impact on the environment.

\section{Conclusions}

The current study's main contribution is to understand the variables that affect entrepreneurship intention. It has been found that the three variables described have a relevant impact on the self-efficacy variable, which is the last variable for the intention of developing ecological enterprises. As the literature is limited to green enterprises, this study seeks to broaden that thematic interest. The analysis technique employed is a strength of this article, as it has permitted correlations to be detected between the same variables using multivariate analysis by modeling structural equations using partial least squares (SEM PLS).

This study could be reproduced in other cities or regions, e.g., Latin America or Europe. However, we need to evaluate each case in detail because each country has its own entrepreneurship efforts, different government rules, and university governance. It has also been possible to develop an instrument that can be applied in future research and refined for further research.

\subsection{Theoretical Implications}

The development of green entrepreneurship and related research is still limited in the academic literature, and little is known about the factors that affect student intentions regarding green entrepreneurship. As a novel feature, we have incorporated into the model the support that students feel internally and externally. Internal support is evaluated from the training courses and the promotion of events, approach to entrepreneurs, and even financing to start ventures. From the external side, government support is evaluated from normative aspects or direct or training support. It is expected that the results for each country may be somewhat different, considering that supports differ from governments and even universities, but are still part of the model of internal-external influences. When using SEM PLS, it has been possible to achieve results that measure both the correlation between variables and the pathway to explain green entrepreneurship.

\subsection{Practical Implications}

In the annual programming in universities, action plans are developed in which it is expected that increasing motivations toward green entrepreneurship will be incorporated. The findings can draw the attention of universities so that they can better know the factors that students see as important and so that they can request from the institutions through changes in the content of courses and development funds to support green enterprises. The utilization by universities of green entrepreneurship content to attract future students is an opportunity not widely used by these institutions.

The future development of green entrepreneurship must be precisely evaluated to know what factors influence it and to recognize what changes are being made by the authorities in universities to increase the development of green entrepreneurship by students. The government can evaluate these changes. Green entrepreneurship is likely to continue to grow and will require additional evaluations in different populations. 
Author Contributions: Conceptualization, A.A.-R., S.M. and S.D.-A.-A.; methodology, A.A.-R., S.M., M.A.R. and S.D.-A.-A.; validation, S.M.; formal analysis, A.A.-R.; investigation, V.G.-I., S.M.; data curation, S.D.-A.-A.; writing—original draft preparation, A.A.-R., S.M., S.D.-A.-A. and M.A.R.; writing-review and editing, A.A.-R., V.G.-I. and M.A.R.; visualization, A.A.-R. V.G.-I., S.M., M.A.R. and S.D.-A.-A. All authors have read and agreed to the published version of the manuscript.

Funding: This research was funded by the authors.

Institutional Review Board Statement: Ethical review and approval were waived for this study because it does not involve any risk to the participant's life or health. No substance has been tested on the participants or put them in danger at any time.

Informed Consent Statement: Patient consent was waived because it would not be part of any medical intervention and no drug substance was to be tested.

Data Availability Statement: The data presented in this study are available on request from the corresponding author.

Conflicts of Interest: The authors declare no conflict of interest.

Ethical Approval \& Informed Consent: All procedures performed in studies involving human participants were by the ethical standards with the 1964 Helsinki Declaration and its later amendments or comparable ethical standards. Informed consent was obtained from all individual participants included in the study.

\section{References}

1. WHO. WHO Coronavirus Disease (COVID-19) Dashboard; WHO: Geneva, Switzerland, 2021.

2. Alvarez-Risco, A.; Del-Aguila-Arcentales, S.; Diaz-Risco, S. Pharmacovigilance as a tool for sustainable development of healthcare in Peru. Pharmacovigil. Rev. 2018, 10, 4-6.

3. Alvarez-Risco, A.; Quiroz-Delgado, D.; Del-Aguila-Arcentales, S. Pharmaceutical care in hypertension patients in a peruvian hospital. Indian J. Public Health Res. Dev. 2016, 7, 183-188. [CrossRef]

4. Alvarez-Risco, A.; Turpo-Cama, A.; Ortiz-Palomino, L.; Gongora-Amaut, N.; Del-Aguila-Arcentales, S. Barriers to the implementation of pharmaceutical care in pharmacies in Cusco, Peru. Pharm. Care Esp. 2016, 18, 194-205.

5. Mejía-Acosta, N.; Alvarez-Risco, A.; Solís-Tarazona, Z.; Matos-Valerio, E.; Zegarra-Arellano, E.; Del-Aguila-Arcentales, S. Adverse drug reactions reported as a result of the implementation of pharmaceutical care in the Institutional Pharmacy DIGEMIDMinistry of Health. Pharm. Care Esp. 2016, 18, 67-74.

6. Enciso-Zarate, A.; Guzmán-Oviedo, J.; Sánchez-Cardona, F.; Martínez-Rohenes, D.; Rodríguez-Palomino, J.C.; Alvarez-Risco, A.; Del-Aguila-Arcentales, S.; Diaz-Risco, S. Evaluation of contamination by cytotoxic agents in colombian hospitals. Pharm. Care Esp. 2016, 18, 241-250.

7. Alvarez-Risco, A.; Del-Aguila-Arcentales, S.; Stevenson, J.G. Pharmacists and mass communication for implementing pharmaceutical care. Am. J. Pharm. Benefits 2015, 7, e125-e126.

8. Alvarez-Risco, A.; Del-Aguila-Arcentales, S. Prescription errors as a barrier to pharmaceutical care in public health facilities: Experience Peru. Pharm. Care Esp. 2015, 17, 725-731.

9. Álvarez-Risco, A.; Arellano, E.Z.; Valerio, E.M.; Acosta, N.M.; Tarazona, Z.S. Pharmaceutical care campaign as a strategy for implementation of pharmaceutical services: Experience Peru. Pharm. Care Esp. 2013, 15, 35-37.

10. Talib, A.F.; Mudhafar, Z.N. The role of clinical pharmacist in reducing drug related problems in hemodialysis patients. Iraqi J. Pharm. Sci. 2021, 29, 223-230.

11. Alvarez-Risco, A.; Van Mil, J.W.F. Pharmaceutical care in community pharmacies: Practice and research in Peru. Ann. Pharmacother. 2007, 41, 2032-2037. [CrossRef] [PubMed]

12. Zhang, S.X.; Sun, S.; Afshar Jahanshahi, A.; Alvarez-Risco, A.; Ibarra, V.G.; Li, J.; Patty-Tito, R.M. Developing and testing a measure of COVID-19 organizational support of healthcare workers—results from Peru, Ecuador, and Bolivia. Psychiatry Res. 2020, 291, 113174. [CrossRef] [PubMed]

13. Yáñez, J.A.; Afshar Jahanshahi, A.; Alvarez-Risco, A.; Li, J.; Zhang, S.X. Anxiety, Distress, and Turnover Intention of Healthcare Workers in Peru by Their Distance to the Epicenter during the COVID-19 Crisis. Am. J. Trop. Med. Hyg. 2020, 103, 1614-1620. [CrossRef]

14. Chen, X.; Zhang, S.X.; Jahanshahi, A.A.; Alvarez-Risco, A.; Dai, H.; Li, J.; Ibarra, V.G. Belief in a COVID-19 conspiracy theory as a predictor of mental health and well-being of health care workers in ecuador: Cross-sectional survey study. JMIR Public Health Surveill 2020, 6, e20737. [CrossRef]

15. Zhang, S.X.; Chen, J.; Afshar Jahanshahi, A.; Alvarez-Risco, A.; Dai, H.; Li, J.; Patty-Tito, R.M. Succumbing to the COVID-19 pandemic-Healthcare workers not satisfied and intend to leave their jobs. Int. J. Ment. Health Addict. 2021, 1-10. [CrossRef]

16. Román, B.R.; Moscoso, S.; Chung, S.A.; Terceros, B.L.; Álvarez-Risco, A.; Yáñez, J.A. Treatment of COVID-19 in peru and bolivia, and self-medication risks. Rev. Cuba. Farm. 2020, 53, 1-20. 
17. Alvarez-Risco, A.; Mejia, C.R.; Delgado-Zegarra, J.; Del-Aguila-Arcentales, S.; Arce-Esquivel, A.A.; Valladares-Garrido, M.J.; Rosas del Portal, M.; Villegas, L.F.; Curioso, W.H.; Sekar, M.C.; et al. The Peru Approach against the COVID-19 Infodemic: Insights and Strategies. Am. J. Trop. Med. Hyg. 2020, 103, 583-586. [CrossRef]

18. Yáñez, J.A.; Alvarez-Risco, A.; Delgado-Zegarra, J. Covid-19 in Peru: From supervised walks for children to the first case of Kawasaki-like syndrome. BMJ 2020, 369, m2418. [CrossRef]

19. Quispe-Cañari, J.F.; Fidel-Rosales, E.; Manrique, D.; Mascaró-Zan, J.; Huamán-Castillón, K.M.; Chamorro-Espinoza, S.E.; GarayarPeceros, H.; Ponce-López, V.L.; Sifuentes-Rosales, J.; Alvarez-Risco, A.; et al. Self-medication practices during the COVID-19 pandemic among the adult population in Peru: A cross-sectional survey. Saudi Pharm. J. 2021, 29, 1-11. [CrossRef] [PubMed]

20. Holzinger, B.; Mayer, L.; Nierwetberg, F.; Klösch, G. COVID-19 lockdown-Are Austrians finally able to compensate their sleep debt? Sleep Med. X 2021, 3, 100032. [CrossRef] [PubMed]

21. Alvarez-Risco, A.; Del-Aguila-Arcentales, S.; Rosen, M.A.; García-Ibarra, V.; Maycotte-Felkel, S.; Martínez-Toro, G.M. Expectations and interests of university students in COVID-19 times about sustainable development goals: Evidence from Colombia, Ecuador, Mexico, and Peru. Sustainability 2021, 13, 3306. [CrossRef]

22. Alvarez-Risco, A.; Estrada-Merino, A.; Anderson-Seminario, M.M.; Mlodzianowska, S.; García-Ibarra, V.; Villagomez-Buele, C.; Carvache-Franco, M. Multitasking behavior in online classrooms and academic performance: Case of university students in Ecuador during COVID-19 outbreak. Interact. Technol. Smart Educ. 2020. In press.

23. Alvarez-Risco, A.; Dawson, J.; Johnson, W.; Conteh-Barrat, M.; Aslani, P.; Del-Aguila-Arcentales, S.; Diaz-Risco, S. Ebola virus disease outbreak: A global approach for health systems. Rev. Cuba. Farm. 2020, 53, 1-13.

24. Carvache-Franco, M.; Alvarez-Risco, A.; Carvache-Franco, O.; Carvache-Franco, W.; Estrada-Merino, A.; Villalobos-Alvarez, D. Perceived value and its influence on satisfaction and loyalty in a coastal city: A study from Lima, Peru. J. Policy Res. Tour. Leis. Events 2021, 1-16. [CrossRef]

25. Alvarez-Risco, A.; Estrada-Merino, A.; Perez-Luyo, R. Sustainable development goals in hospitality management. In Sustainable Hospitality Management, Ruël, H., Lombarts, A., Eds.; Emerald Publishing Limited: Bradford, UK, 2020; Volume 24, pp. 159-178.

26. Carvache-Franco, M.; Carvache-Franco, O.; Carvache-Franco, W.; Alvarez-Risco, A.; Estrada-Merino, A. Motivations and segmentation of the demand for coastal cities: A study in Lima, Peru. Int. J. Tour. Res. 2020, 1-15. [CrossRef]

27. Yan, J.; Kim, S.; Zhang, S.X.; Foo, M.-D.; Alvarez-Risco, A.; Del-Aguila-Arcentales, S.; Yáñez, J.A. Hospitality workers' COVID-19 risk perception and depression: A contingent model based on transactional theory of stress model. Int. J. Hosp. Manag. 2021, 95, 102935. [CrossRef]

28. Barth, B. Ghosts in the office. Planning 2021, 87, 24-30.

29. Laing, T. The economic impact of the Coronavirus 2019 (Covid-2019): Implications for the mining industry. Extr. Ind. Soc. 2020, 7, 580-582. [CrossRef]

30. Liguori, E.; Winkler, C. From offline to online: Challenges and opportunities for entrepreneurship education following the COVID-19 Pandemic. Entrep. Educ. Pedagog. 2020, 3, 346-351. [CrossRef]

31. van Zanten, J.A.; van Tulder, R. Beyond COVID-19: Applying "SDG logics" for resilient transformations. J. Int. Bus. Policy 2020, 3, 451-464. [CrossRef]

32. Alvarez-Risco, A.; Rose, M.A.; Del-Aguila-Arcentales, S. A new regulation for supporting a circular economy in the plastic industry: The case of Peru (Short communication). J. Landsc. Ecol. 2020, 13, 1-3. [CrossRef]

33. Lamont, L.M. Entrepreneurship, technology, and the university. RD Manag. 1972, 2, 119-123. [CrossRef]

34. Hay, D.R. A Canadian university experience in technological innovation and entrepreneurship. Technovation 1981, 1, 43-55. [CrossRef]

35. Segal, N.S. Universities and technological entrepreneurship in Britain: Some implications of the Cambridge phenomenon. Technovation 1986, 4, 189-204. [CrossRef]

36. McMullan, W.E.; Long, W.A.; Graham, J.B. Assessing economic value added by university-based new-venture outreach programs. J. Bus. Ventur. 1986, 1, 225-240. [CrossRef]

37. Hills, G.E. Variations in University entrepreneurship education: An empirical study of an evolving field. J. Bus. Ventur. 1988, 3, 109-122. [CrossRef]

38. Hopkins, T.; Feldman, H. Changing entrepreneurship education: Finding the right entrepreneur for the job. J. Organ. Chang. Manag. 1989, 2, 28-40. [CrossRef]

39. Frazier, J.W. A Partnership for Environmentally-and Educationally-Based Economic Development in Poland; Department of Geography, The University Center at Binghamton, State University of New York: New York, NY, USA, 1991; Volume 14.

40. Johannisson, B. University training for entrepreneurship: Swedish approaches. Entrep. Reg. Dev. 1991, 3, 67-82. [CrossRef]

41. van der Sijde, P.C.; van Alsté, J.A. Support for Entrepreneurship at the University of Twente. Ind. High. Educ. 1998, 12, 367-372. [CrossRef]

42. Tamkivi, R. Support Structures for Innovation and Research-Based Entrepreneurship in Estonia. Ind. High. Educ. 1999, 13, 46-53. [CrossRef]

43. Watkins, D.; Stone, G. Entrepreneurship Education in UK HEIs: Origins, Development and Trends. Ind. High. Educ. 1999, 13, 382-389. [CrossRef]

44. Klofsten, M.; Jones-Evans, D. Comparing Academic Entrepreneurship in Europe-The Case of Sweden and Ireland. Small Bus. Econ. 2000, 14, 299-309. [CrossRef] 
45. Virtanen, M.; Laukkanen, M. Towards HEI-Based New Venture Generation: The Business Lab of the University of Kuopio, Finland. Ind. High. Educ. 2002, 16, 159-166. [CrossRef]

46. Campanella, F.; Della Peruta, M.R.; Del Giudice, M. The role of sociocultural background on the characteristics and the financing of youth entrepreneurship. An Exploratory Study of University Graduates in Italy. J. Knowl. Econ. 2013, 4, 244-259. [CrossRef]

47. Klandt, H.; Volkmann, C. Development and Prospects of Academic Entrepreneurship Education in Germany. High. Educ. Eur. 2006, 31, 195-208. [CrossRef]

48. Edwards, L.J.; Muir, E.J. Promoting entrepreneurship at the University of Glamorgan through formal and informal learning. J. Small Bus. Enterp. Dev. 2005, 12, 613-626. [CrossRef]

49. Karanassios, N.; Pazarskis, M.; Mitsopoulos, K.; Christodoulou, P. EU Strategies to Encourage Youth Entrepreneurship: Evidence from Higher Education in Greece. Ind. High. Educ. 2006, 20, 43-50. [CrossRef]

50. Coduras, A.; Urbano, D.; Rojas, Á.; Martínez, S. The Relationship Between University Support to Entrepreneurship with Entrepreneurial Activity in Spain: A gem data based analysis. Int. Adv. Econ. Res. 2008, 14, 395-406. [CrossRef]

51. Ferreira, J.; Raposo, M.; do Paço, A. Entrepreneur's profile: A taxonomy of attribu tes and motivations of university students. J. Small Bus. Enterp. Dev. 2008, 15, 405-418.

52. Huu-Phuong, T.; Soo-Jiuan, T. Export Factoring: A Strategic Alternative for Small Exporters in Singapore. Int. Small Bus. J. 1990, 8, 49-57. [CrossRef]

53. Menning, G. Trust, entrepreneurship and development in Surat city, India. Ethnos 1997, 62, 59-90. [CrossRef]

54. Suzuki, K.-i.; Kim, S.-H.; Bae, Z.-T. Entrepreneurship in Japan and Silicon Valley: A comparative study. Technovation 2002, 22, 595-606. [CrossRef]

55. Mok, K.H. Fostering entrepreneurship: Changing role of government and higher education governance in Hong Kong. Res. Policy 2005, 34, 537-554. [CrossRef]

56. Yu Cheng, M.; Sei Chan, W.; Mahmood, A. The effectiveness of entrepreneurship education in Malaysia. Educ. Train. 2009, 51, 555-566. [CrossRef]

57. Millman, C.; Matlay, H.; Liu, F. Entrepreneurship education in China: A case study approach. J. Small Bus. Enterp. Dev. 2008, 15, 802-815. [CrossRef]

58. Mitra, J. Nurturing and sustaining entrepreneurship: University, Science Park, Business and Government Partnership in Australia. Ind. High. Educ. 2000, 14, 183-190. [CrossRef]

59. Jesselyn Co, M.; Mitchell, B. Entrepreneurship education in South Africa: A nationwide survey. Educ. Train. 2006, 48, 348-359. [CrossRef]

60. Owusu-Mintah, S. Entrepreneurship education and job creation for tourism graduates in Ghana. Educ. Train. 2014, 56, 826-838. [CrossRef]

61. Olokundun, M.; Iyiola, O.; Ibidunni, S.; Ogbari, M.; Falola, H.; Salau, O.; Peter, F.; Borishade, T. Data article on the effectiveness of entrepreneurship curriculum contents on entrepreneurial interest and knowledge of Nigerian university students. Data Brief 2018, 18, 60-65. [CrossRef] [PubMed]

62. Chrisman, J.J.; Hynes, T.; Fraser, S. Faculty entrepreneurship and economic development: The case of the University of Calgary. J. Bus. Ventur. 1995, 10, 267-281. [CrossRef]

63. Dill, D.D. University-industry entrepreneurship: The organization and management of American university technology transfer units. High. Educ. 1995, 29, 369-384. [CrossRef]

64. Bernasconi, A. University entrepreneurship in a developing country: The case of the P. Universidad Católica de Chile, 1985-2000. High. Educ. 2005, 50, 247-274. [CrossRef]

65. Postigo, S.; Tamborini, M.F. Entrepreneurship education in Argentina: The case of the San Andres University. In Business Education and Emerging Market Economies: Perspectives and Best Practices; Alon, I., McLntyre, J.R., Eds.; Springer US: Boston, MA, USA, 2004; pp. 267-282.

66. Chafloque-Cespedes, R.; Alvarez-Risco, A.; Robayo-Acuña, P.-V.; Gamarra-Chavez, C.-A.; Martinez-Toro, G.-M.; Vicente-Ramos, W. Effect of sociodemographic factors in entrepreneurial orientation and entrepreneurial intention in university students of Latin American business schools. In Universities and Entrepreneurship: Meeting the Educational and Social Challenges; Kakouris, A., Moon, C., Walmsley, A., Apostolopoulos, N., Jones, P., Ratten, V., Eds.; Emerald Publishing Limited: Bingley, UK, 2021; Volume 11, pp. 151-165.

67. Silajdžić, I.; Kurtagić, S.M.; Vučijak, B. Green entrepreneurship in transition economies: A case study of Bosnia and Herzegovina. J. Clean. Prod. 2015, 88, 376-384. [CrossRef]

68. Lynskey, M.J. Bioentrepreneurship in Japan: Institutional transformation and the growth of bioventures. J. Commer. Biotechnol. 2004, 11, 9-37. [CrossRef]

69. Bonnet, H.; Quist, J.; Hoogwater, D.; Spaans, J.; Wehrmann, C. Teaching sustainable entrepreneurship to engineering students: The case of Delft University of Technology. Eur. J. Eng. Educ. 2006, 31, 155-167. [CrossRef]

70. Wach, K.; Głodowska, A.; Maciejewski, M. Entrepreneurial orientation, knowledge utilization and internationalization of firms. Sustainability 2018, 10, 4711. [CrossRef]

71. Fishbein, M.; Ajzen, I. Belief, Attitude, Intention, and Behavior: An Introduction to Theory and Research; Addison-Wesley: Boston, MA, USA, 1977.

72. Bandura, A. Social Foundations of Thought and Action: A Social Cognitive Theory; Prentice-Hall, Inc.: Englewood Cliffs, NJ, USA, 1986. 
73. Miller, D. The correlates of entrepreneurship in three types of firms. Manag. Sci. 1983, 29, 770-791. [CrossRef]

74. Lumpkin, G.T.; Dess, G.G. Clarifying the entrepreneurial orientation construct and linking it to performance. Acad. Manag. Rev. 1996, 21, 135-172. [CrossRef]

75. Bird, B. Implementing entrepreneurial ideas: The case for intention. Acad. Manag. Rev. 1988, 13, 442-453. [CrossRef]

76. Meoli, A.; Fini, R.; Sobrero, M.; Wiklund, J. How entrepreneurial intentions influence entrepreneurial career choices: The moderating influence of social context. J. Bus. Ventur. 2020, 35, 105982. [CrossRef]

77. Santos Susana, C.; Liguori Eric, W. Entrepreneurial self-efficacy and intentions: Outcome expectations as mediator and subjective norms as moderator. Int. J. Entrep. Behav. Res. 2019, 26, 400-415. [CrossRef]

78. Conner, M. Theory of planned behavior. In Handbook of sport psychology; John Wiley \& Sons: Hoboken, NJ, USA, 2020; pp. 1-18. [CrossRef]

79. Rauch, A.; Hulsink, W. Putting entrepreneurship education where the intention to act lies: An investigation into the impact of entrepreneurship education on entrepreneurial behavior. Acad. Manag. Learn. Educ. 2015, 14, 187-204. [CrossRef]

80. Neneh, B.N. From entrepreneurial intentions to behavior: The role of anticipated regret and proactive personality. J. Vocat. Behav. 2019, 112, 311-324. [CrossRef]

81. Farinelli, F.; Bottini, M.; Akkoyunlu, S.; Aerni, P. Green entrepreneurship: The missing link towards a greener economy. ATDF J. 2011, 8, 42-48.

82. Fichter, K.; Tiemann, I. Factors influencing university support for sustainable entrepreneurship: Insights from explorative case studies. J. Clean. Prod. 2018, 175, 512-524. [CrossRef]

83. Bergmann, H.; Geissler, M.; Hundt, C.; Grave, B. The climate for entrepreneurship at higher education institutions. Res. Policy 2018, 47, 700-716. [CrossRef]

84. da Silva Moreira Ferreira, A.; Loiola, E.; Guedes Gondim, S.M. Motivations, business planning, and risk management: Entrepreneurship among university students. INMR Innov. Manag. Rev. 2017, 14, 140-150. [CrossRef]

85. Bandura, A. Self-efficacy mechanism in psychobiologic functioning. In Self-Efficacy: Thought Control of Action; Hemisphere Publishing Corp: Washington, DC, USA, 1992; pp. 355-394.

86. Krueger, N.F.; Reilly, M.D.; Carsrud, A.L. Competing models of entrepreneurial intentions. J. Bus. Ventur. 2000, 15, 411-432 [CrossRef]

87. Newman, A.; Obschonka, M.; Schwarz, S.; Cohen, M.; Nielsen, I. Entrepreneurial self-efficacy: A systematic review of the literature on its theoretical foundations, measurement, antecedents, and outcomes, and an agenda for future research. J. Vocat. Behav. 2019, 110, 403-419. [CrossRef]

88. Shahab, Y.; Chengang, Y.; Arbizu Angel, D.; Haider Muhammad, J. Entrepreneurial self-efficacy and intention: Do entrepreneurial creativity and education matter? Int. J. Entrep. Behav. Res. 2019, 25, 259-280. [CrossRef]

89. Mei, H.; Ma, Z.; Jiao, S.; Chen, X.; Lv, X.; Zhan, Z. The sustainable personality in entrepreneurship: The relationship between big six personality, entrepreneurial self-efficacy, and entrepreneurial intention in the chinese context. Sustainability 2017, 9, 1649. [CrossRef]

90. Kumar, R.; Shukla, S. Creativity, proactive personality and entrepreneurial intentions: Examining the mediating role of entrepreneurial self-efficacy. Glob. Bus. Rev. 2019, 0972150919844395. [CrossRef]

91. Asimakopoulus, G.; Hernández, V.; Peña Miguel, J. Entrepreneurial intention of engineering students: The role of social norms and entrepreneurial self-efficacy . Sustainability. 2019, 11, 4314. [CrossRef]

92. Tajvidi, R.; Tajvidi, M. The growth of cyber entrepreneurship in the food industry: Virtual community engagement in the COVID-19 era. Br. Food J. 2020. In press . [CrossRef]

93. Wegner, D.; Thomas, E.; Teixeira Eduardo, K.; Maehler Alisson, E. University entrepreneurial push strategy and students entrepreneurial intention. Int. J. Entrep. Behav. Res. 2019, 26, 307-325. [CrossRef]

94. Soria-Barreto, K.; Zúñiga-Jara, S.; Ruiz Campo, S. Determinantes de la intención emprendedora: Nueva evidencia. Interciencia 2016, 41, 325-329.

95. Moriano, J.A.; Trejo, E.; Palací, F.J. The psychosocial profile of the entrepreneur [El perfil psicosocial del emprendedor]. Rev. Psico Soc. 2001, 16, 229-242. [CrossRef]

96. Liñán, F.; Chen, Y.W. Development and Cross-Cultural Application of a Specific Instrument to Measure Entrepreneurial Intentions. Entrep. Theory Pract. 2009, 33, 593-617. [CrossRef]

97. Ringle, C.M.; Wende, S.; Becker, J.M. SmartPLS 3; Boenningstedt: SmartPLS GmbH: Bönningstedt, Germany, 2015.

98. Fornell, C.; Larcker, D.F. Evaluating structural equation models with unobservable variables and measurement error. J. Mark. Res. 1981, 18, 39-50. [CrossRef]

99. Lopez-Odar, D.; Alvarez-Risco, A.; Vara-Horna, A.; Chafloque-Cespedes, R.; Sekar, M.C. Validity and reliability of the questionnaire that evaluates factors associated with perceived environmental behavior and perceived ecological purchasing behavior in Peruvian consumers. Soc. Responsib. J. 2019, 16, 403-417. [CrossRef]

100. Streukens, S.; Leroi-Werelds, S. Bootstrapping and PLS-SEM: A step-by-step guide to get more out of your bootstrap results. Eur. Manag. J. 2016, 34, 618-632. [CrossRef]

101. Shi, L.; Yao, X.; Wu, W. Perceived university support, entrepreneurial self-efficacy, heterogeneous entrepreneurial intentions in entrepreneurship education. J. Entrep. Emerg. Econ. 2020, 12, 205-230. [CrossRef] 
102. Mozahem, N.A.; Adlouni, R.O. Using entrepreneurial self-efficacy as an indirect measure of entrepreneurial education. Int. J. Manag. Educ. 2020, 19, 100385. [CrossRef]

103. Wardana, L.W.; Narmaditya, B.S.; Wibowo, A.; Mahendra, A.M.; Wibowo, N.A.; Harwida, G.; Rohman, A.N. The impact of entrepreneurship education and students' entrepreneurial mindset: The mediating role of attitude and self-efficacy. Heliyon 2020, 6, e04922. [CrossRef] [PubMed]

104. The University of Melbourne. Master of Entrepreneurship. Available online: https://study.unimelb.edu.au/find/courses/ graduate/master-of-entrepreneurship/ (accessed on 15 May 2021).

105. University of Alberta. Innovation \& Entrepreneurship. Available online: https://www.ualberta.ca/business/programs/mba/ degree-programs/innovation-entrepreneurship.html (accessed on 15 May 2021)

106. Burnette, J.L.; Pollack, J.M.; Forsyth, R.B.; Hoyt, C.L.; Babij, A.D.; Thomas, F.N.; Coy, A.E. A growth mindset intervention: Enhancing students' entrepreneurial self-efficacy and career development. Entrep. Theory Pract. 2019, 44, 878-908. [CrossRef]

107. van der Westhuizen, T.; Goyayi, M.J. The influence of technology on entrepreneurial self-efficacy development for online business start-up in developing nations. Int. J. Entrep. Innov. 2019, 21, 168-177. [CrossRef]

108. Cadenas, G.A.; Cantú, E.A.; Lynn, N.; Spence, T.; Ruth, A. A programmatic intervention to promote entrepreneurial self-efficacy, critical behavior, and technology readiness among underrepresented college students. J. Vocat. Behav. 2020, 116, 103350. [CrossRef]

109. Elnadi, M.; Gheith, M.H. Entrepreneurial ecosystem, entrepreneurial self-efficacy, and entrepreneurial intention in higher education: Evidence from Saudi Arabia. Int. J. Manag. Educ. 2021, 100458. [CrossRef]

110. University of Oxford. Think Tanks. Available online: https://www.careers.ox.ac.uk/think-tanks\#/ (accessed on 15 May 2021).

111. Harvard Kennedy School. Think Tank Search. Available online: https://guides.library.harvard.edu/hks/think_tank_search/US (accessed on 15 May 2021).

112. Memon, M.; Soomro Bahadur, A.; Shah, N. Enablers of entrepreneurial self-efficacy in a developing country. Educ. Train. 2019, 61, 684-699. [CrossRef]

113. Nowiński, W.; Haddoud, M.Y.; Wach, K.; Schaefer, R. Perceived public support and entrepreneurship attitudes: A little reciprocity can go a long way! J. Vocat. Behav. 2020, 121, 103474. [CrossRef]

114. Soomro, B.A.; Ghumro, I.A.; Shah, N. Green entrepreneurship inclination among the younger generation: An avenue towards a green economy. Sustain. Dev. 2020, 28, 585-594. [CrossRef] 